Transactions of the Royal Asiatic Society of Great Britain and Ireland http://journals.cambridge.org/TRA

Additional services for Transactions of the Royal Asiatic Society of Great Britain and Ireland:

Email alerts: Click here

Subscriptions: Click here

Commercial reprints: Click here

\title{
VI. Geographical Notice of the Frontiers of the Burmese and Chinese Empires, with the Copy of a Chinese Map
}

John Francis Davis

Transactions of the Royal Asiatic Society of Great Britain and Ireland / Volume 2 / Issue 01 / March 1830, pp 90 - 94
DOl: 10.1017/S0950473700001324, Published online: 19 November 2009

Link to this article: http://journals.cambridge.org/abstract_ S0950473700001324

How to cite this article:
John Francis Davis (1830). VI. Geographical Notice of the Frontiers of the Burmese and Chinese Empires, with the Copy of a Chinese Map. Transactions of the Royal Asiatic Society of Great Britain and Ireland, 2, pp 90-94 doi:10.1017/S0950473700001324

Request Permissions : Click here 
VI. Geographical Notice of the Frontiers of the Burmese and Chinese Empires, with the Copy of a Chinese Map. By JoHN FrancIS Davis, Esq., M.R.A.S.

Read December 15, 1827.

THE great interest which now attaches to the geography of the Burmese empire and to its relations with the Chinese, seems to call for as much information as can by any means be procured on these subjects from different quarters. In the Chinese library of the East-India Company at Canton is a MS. map, chiefly compiled from the labours of the missionaries; and as its extreme accuracy can be vouched for with respect to those parts of the empire through which Lord Amherst's embassy passed, it is entitled to a degree of credit, which is not hastily to be awarded to Chinese maps in general. An exact copy has been taken from this map of the western part of Yun-nan province. Our latest geographical knowledge of the Burmese country is contained in a map recently published at Calcutta, with the permission of the Bengal government; and as that portion which relates to the Chinese frontier was likely to have been obtained from Burmese sources, it may be worth while to compare it with the Chinese map. As far as relates to the names of places, the Chinese character is the only sure guide within their own territory. Little accuracy can be expected from, or stress laid on, the names written by one set of strangers, the English, and obtained by them through the mouths, or the writing, of another set of strangers, the Burmese. Notwithstanding this difficulty, howerer, it will perhaps be found that a considerable degree of correspondence exists between the two maps.

The great river 落江 Loo-lieang forms, according to both maps, the boundary of the Chinese empire from lat. $27^{\circ}$ to $26^{\circ}$, where it enters Yunnan province, and issuing from it again about lat. $21^{\circ}$, proceeds nearly due south. Serving, during a considerable part of its course, as the boundary 


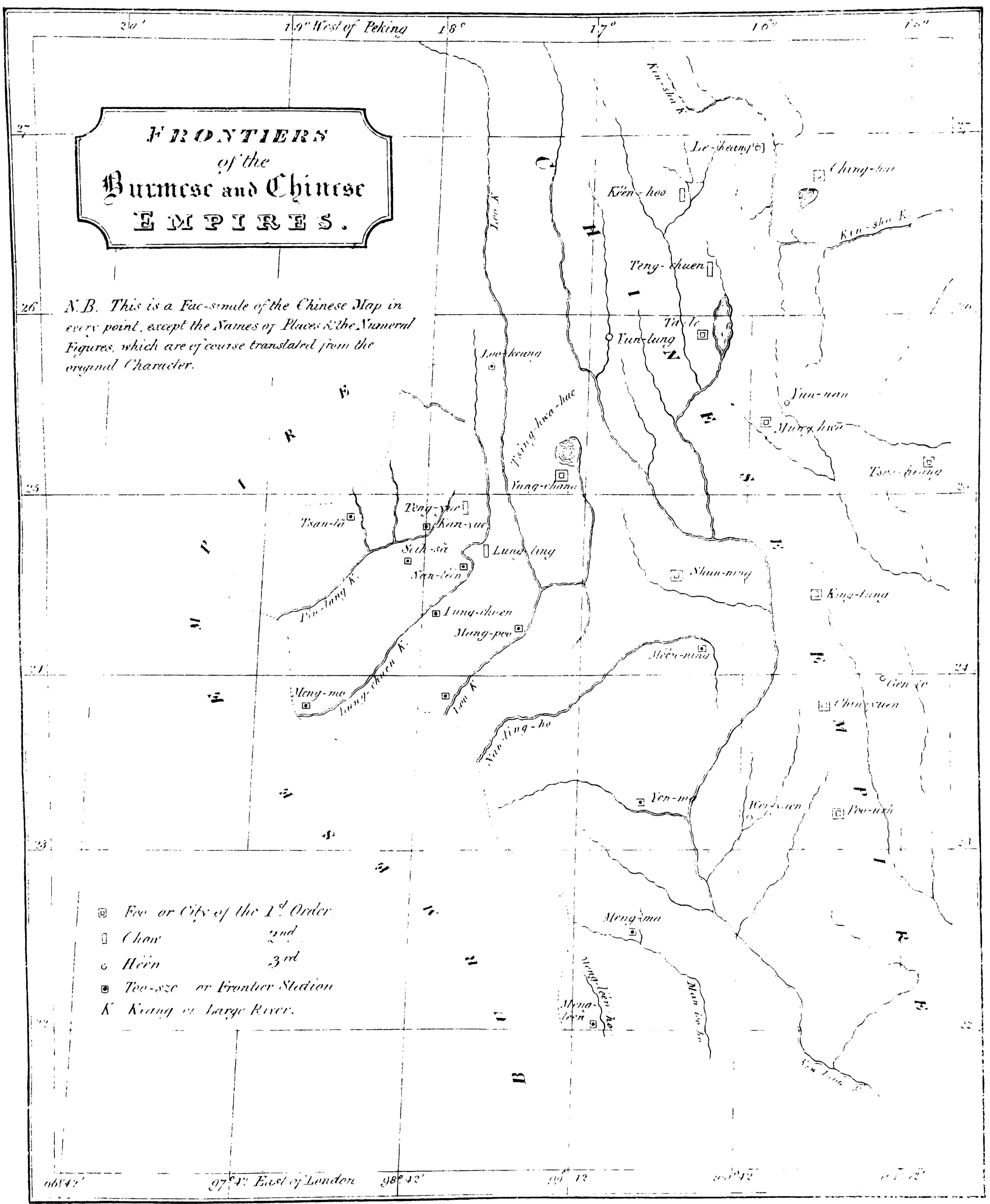

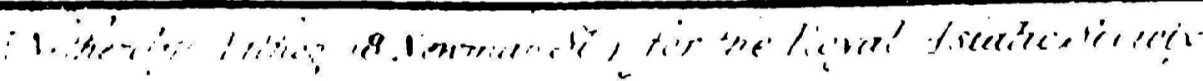


line of Ava and Siam, it empties itself into the sea below Martaban, after performing a course of more than 660 geographical miles. The map of the Chinese, however, does not extend in any part beyond their own frontier.

In the Chinese map, immediately on the border of Yun-nan, and just below $25^{\circ}$ lat., we find a place called 盄達 Tsan-tă, the Santa of the English map. This is distinguished by Du Halde with the title of 府 Foo, or city of the first order: while in the MS. map it is merely put down as a 土司 Too-sze, and there is no chief city to the westward of 永昌府 Yung-chang-Foo. On the outskirts of the Chinese empire, 交界 Keaoukeae ("where the frontiers blend,") towards the west, are a number of towns or stations called by them 土司Too-sze, where the original natives of the country are more or less independent, and where there is in fact a kind of divided authority, each party being immediately subject to its own chiefs. This is particularly the case of the Meaou-tsze and Lo-los. The Chinese map mentions Tsan-tă, or Santa, as one of these stations, and not as a chief town; and Du Halde himself observes of it: "Cette dernière ville, qui confine avec le royaume d'Ava, est proprement une ville de guerre, pour servir de defense à cette frontière :" which description does not correspond with what the Chinese call a Foo.

The 檳楖江 Pin-lang-Keang of the Chinese map, flowing into the Burmese territory immediately below $T$ san-t $\breve{a}$, is called in our map Pan-molieang, and represented as united with the Irawadi at Bhan-mo, or Pan-mo; while the 龍虎川江Lung-chuen-Keang, a little below to the southward, is named Shueli Myeet, and also flows into the Irawadi. The relative position of these two rivers is pretty nearly the same in both maps, but there is considerable disagreement in the position of the towns or stations on their borders; and on this subject it is probable that the Chinese map is best entitled to credit of the two. In the latter, advancing from the frontier inwards, on the Lung-chuen river, we see 猛印 Meng-maou, or Meng-mo, 龍川 Lung-chuen, 南甸 Nan-tëen, and 騰越Teng-yuc， the three former marked as Too-sze, and the last as a Chow, or town of the second order. In the English map, however, the first station is Lungchuen (improperly written Fou-se, instead of Too-sze); the second N'an$\mathrm{N} 2$ 
taen (Nan-ẗen), and the third Tong-ye-chew (Teng-yǚ-chow), constituting the three first stages on the route from Ava towards Yun-nan city: and these three stations are placed on the northern stream, corresponding with the Pin-lang-Keang, instead of that which answers to the Lung-chuenKeang of the Chinese map, to the southward. Now I should think, from the name of the first of these, Lung-chuen, that it is properly placed in the MS. map on Lung-chuen river, and consequently the two others; and that the route towards Yun-nan, in fact, lies on the southern stream instead of the northern. Were this found to be the fact, Lang-chuen-Keang would also be the real Bhan-mo or Pan-mo-Keang. This seems to be confirmed by the Chinese map. Below Lung-chuen station towards Ava, we find immediately on the border Meng-maou, or as it is pronounced in the south, Meng-mo, which I think is very likely to be intended for Bhan-mo or Panmo, called Bamoo by Symes, and stated by him to be the chief point of commercial intercourse between the two countries. The spirit of Chinese encroachment might be disposed to include this in their own map, with some violation of its real locality.

With respect to the route laid down in the English map, from Bhan-mo through Yang-chang-Foo and Ta-le-Foo, towards Fun-nan city, it is not likely that the natives of Ava are frequently allowed to enter so far into the Chinese territory. This is more probably the track of the merchants and emissaries of the latter, in their commercial speculations towards the frontier. Symes states, that the Chinese envoys, whom he found at Amerapura, were, as far he could ascertain, merely a provincial deputation, and not imperial ambassadors from Peking. This indeed is most likely, being in unison with the general maxims of Chinese foreign policy. They say, " attach no value to what is foreign, and strangers will resort to you."

It is deserving of notice, that Mancheegee is mentioned by Symes as the Burmese name for Yun-nan; and that Mangee is the name given by Marco Polo to the southern part of China. The northern he calls Cathay.

The country which forms the western part of Yun-nan province is allowed to be mountainous, wild, and thinly peopled; and I understand from Père L'Amiot, who has resided more than thirty years at Peking, that it is considered by the Chinese as unhealthy. It was his fortune to fall in with a Tartar oficer who had served in the army sent against the Burmese empire in $176 \%$, and stated by Symes to have amounted to fifty thousand men, of which army very few individuals escaped back to their own country. The 
total failure of this great enterprize was attributed by the said Tartar officer to the unhealthiness of the climate: but when a due aliowance has been made for the influence of national feeling and Chinese want of candour, a considerable portion of their disasters may be referred to the prowess of the invaded enemy.

The stream, called in the MS. map 淂路河 Man-loo-Ho, seems to be the commencement of the great river of Siam, which reache; the sea at Bankok.

The 九龍江 Keu-lung-Keang, or river of the nine dragons, which after collecting a number of tributary streams in Iun-nan prosince, traverses an immense expanse, and finally empties itself into the sea at the southern extremity of Cambodia, does not yield to the Yang-tsze-Keang itself in the length of its course, and may be classed among the principal rirers of our globe.

Père L'Amiot, at my particular request, obligingly supplied me with some detached notes relating to Yun-nan province; and I have his permission to subjoin a selection from them :

“ La province de Yun-nan est régie par un Tsung-too, ou viceroi, qui gouverne aussi la province de Krei-chow. Il y a de plus, un gouverneur particulier, appellé Seun-foo........ Terres cultivées du peuple 83,603 tsing ; * fermes du gouvernement 9,288 tsing; terres d'étrangers non reputés Chinois, 824 tuon: j'ignore en quoi consiste cette portion de terre; tuon est une expression générale, indéterminée dans l'usage ordinaire, mais determinée pour le lieu même......... Cette province n'a été soumis aux Chinois que dans les derniers tems, après la resistance la plus opiniâtre, et des efforts prodigieux. L'intemperie du climat si funeste aux Chinois, la difficulté de pénétrer dans ces affreuses montagnes, et peut-être aussi le caractère des habitans ont produit une lutte longue et terrible. On cite le nom et les hauts faits de ceux qui ont le plus contribués a surmonter ces obstacles. On en voit qui s'appliquent à soulager le peuple, le formant à la doctrine, mœurs, usages, et arts des Chinois; perfectionnant l'agriculture, reformant les mœurs, dont le débordement étoit affreux......... Les troubles continuent sous les premiers règnes de la dynastie actuelle, et sont fortement comprimés; depuis un certain temps on y voit les lois en vigueur, et la paix

* Nine hundred mow, or Chinese acres, constitute a tsing. 
solidement établie..........La resistance que les naturels opposent à la domination Chinoise est toujours appellée revolte, parceque tous les peuples sont de plein droit soumis au fils de ciel, père et mère de l'univers..........La ville de Pou-eul (Poo-urh-Foo, see map), a quatre lee de circuit. La population n'est pas connue, parcequ'elle est composée en partie des naturels du pays. La montagne nommée Pou-eul est renommée pour une espèce de thé, qui est portée à Pekin, et offerte à l'Empereur en boules, ou en tablettes qui sont des extraits de ce même thé : à Pekin on le procure facilement.........Le district de Yung-tchang-fou (Yung-chang-Foo in the map) renferme une ville et district du $\mathfrak{2}^{e}$ ordre, une du $3^{\mathrm{e}}$ ordre, et quelques petits districts séparés, qui paroissent habités par les naturels du pays. Il est souvent parlé des combats terribles que les naturels ont soutenus contre les Chinois; il leur reste encore des lieux de refuge que les Chinois respectent. ......... On tire des rivières de l'ambre, du corail, des perles. Ces rivières sont en grande nombre: une d'elles (probably meaning the Loo-Keang) communique avec la mer au midi.........Les mandarinats de quelques districts sont héréditaires parmi les habitans du pays......... On parle de diverses peuples situées à la distance de 20 et 30 journées sud-ouest de Yun-nan-Foo. On dit que c'est̂ l'ancienne patrie des naturels de Funn-nan. Ils reconnoissent l'empereur; lui payent une redevance annuelle; leur chef est choisi parmi les descendans d'une même famille. Ils ont une mine d'or ......... Déjà sous les Han les Chinois avoient des colonies dans la province de Yun-nan, mais ils n'en ont été paisibles possesseurs que dans ces derniers temps.........il est parlé parfois de faits et de monumens anciens ; mais ils ne se rattachent pas à l'histoire: ce sont probablement des traditions populaires........Q.uant aux naturels, on voit que ce sont diverses peuplades de différentes races. Ils sont peu connus, peut-être ne sont-ils pa sans intérêt. Pendant bien des siècles ils se sont vigoureusement defendu contre les Chinois. Peut-être sont ils encore en force, quoiqu'ils ne se battent plus, ou rarement.......... On sait que le Fun-nan est très-riche en mines; et que le gouvernement en tire grand partie." 